\title{
Impacts of Plant Growth-Promoting Rhizobacteria on Tropical Forage Grass in Brazil
}

\author{
Monyck Jeane dos Santos Lopes \\ Museu Paraense Emílio Goeldi (MPEG), Department of Botany, Belém, PA, \\ 66040-170, Brazil (present address); Federal Rural University of Amazonia (UFRA), Institute \\ of Agricultural Sciences, Plant Protection Laboratory, Belém, PA, 66077-830, Brazil (work \\ was carried out). E-mail: monycklopes@museu-goeldi.br
}

Moacyr Bernardino Dias-Filho

Brazilian Agricultural Research Corporation (Embrapa), Belém, PA, 66017-970, Brazil. E-mail: moacyr.dias-filho@embrapa.br

Thomaz Henrique dos Reis Castro

Federal Rural University of Amazonia (UFRA), Institute of Agricultural Sciences, Plant Protection Laboratory, Belém, PA, 66077-830, Brazil.

E-mail: thomaz_castro01@ hotmail.com

\section{Edilson Ferreira da Silva}

Department of Botany, Museu Paraense Emílio Goeldi - MPEG, Belém, PA, 66077-830, Brazil. E-mail: freitasdasilva20@yahoo.com.br

\section{Marcela Cristiane Ferreira Rêgo}

Federal Rural University of Amazonia (UFRA), Institute of Agricultural Sciences, Plant Protection Laboratory, Belém, PA, 66077-830, Brazil. E-mail: mcfrego@yahoo.com.br

\section{Gisele Barata da Silva (Corresponding author)}

Federal Rural University of Amazonia (UFRA), Institute of Agricultural Sciences, Plant Protection Laboratory, Belém, PA, 66077-830, Brazil. E-mail: giselebaratasilva@gmail.com 


\begin{abstract}
The aim of this study was to evaluate the effects of plant growth-promoting rhizobacteria effects on anatomical characteristics and nutritional value of Brachiaria (Syn. Urochloa) brizantha cv. BRS Piatã. The experimental design applied was completely randomized design with three treatments: (1) non-inoculated unfertilized-control plants (C-), (2) non-inoculated fertilized-control plants (C+) and (3) B. brizantha inoculated with Pseudomonas fluorescens (BRM-32111) and Burkholderia pyrrocinia (BRM-32113). The following parameters were evaluated at 35 days after seedling emergence: biomass production, plant height, net photosynthesis $(A)$, water-use efficiency (WUE), chlorophyll (SPAD), anatomical and nutritional. The rhizobacteria modified the anatomy of the leaf, culm and roots of $B$. brizantha. They also increased the chlorophyll content, $A, W U E$, total soluble carbohydrates, starch and crude protein contents, $\mathrm{N}, \mathrm{P}, \mathrm{Mg}$ and Fe concentrations, plant height, root area and biomass production. Therefore, we conclude that co-inoculation with $P$. fluorescens (BRM-32111) and B. pyrrocinia (BRM-32113) modified the anatomy and biochemistry of $B$. brizantha, promoting growth and nutrient accumulation. Therefore, these findings set up the basis for additional exploratory studies, using these rhizobacteria as biotechnological innovation with potential of use as biofertilizer in $B$. brizantha, aiming higher productivity and nutritive value in a more eco-friendly and sustainable pasture production system.
\end{abstract}

Keywords: biofertilizer, nutrients, Brachiaria (Syn. Urochola), sustainable pasture production

\title{
1. Introduction
}

Improving forage grasses productivity and nutritive value is an important tool for increasing ecosystem services in tropical pastures (Dias-Filho and Lopes, 2019a). Throughout tropical Latin America and, particularly, in Brazil, Brachiaria (Syn. Urochloa), grasses are the most widely sown forages, and $B$. brizantha stands out as a major species (Reis et al., 2013; Pontes et al., 2017; Pagano et al., 2017). Among the commercially available cultivars of B. brizantha BRS Piatã stands out for its high leaf/stem ratio and improved adaptability to integrated crop-livestock system (Dias-Filho and Lopes, 2019a).

Beneficial plant-microbiome interactions are considered microbial biotechnology a promising solution for a more eco-friendly and sustainable pasture production (Pagano et al., 2017; Duchene et al., 2017; Bhat et al., 2019). Plant growth promoting rhizobacteria (PGPR) encourages the plants growth by either indirect or direct mechanisms (Richardson et al., 2009; Pii et al., 2015; Bhat et al., 2019). As indirect mechanism, they act as bio-control agents, increasing plant resistance to biotic and abiotic stresses. As direct mechanism, they behave as plant phytohormones and as biofertilizer by increasing the availability of soil nutrients, root area and nutrient absorption capacity, affecting biochemical mechanisms and nutritional status, increasing plant growth and yield. 
Low soil fertility is a common limitation to forage grass production in the tropics; under this scenario, chemical fertilization is a major requirement for the intensification of pasture production (Dias-Filho and Lopes, 2019b). However, the use of chemical fertilization, particularly that of nitrogen, poses economic and environmental constraints (Reis et al., 2019; Dias-Filho, 2011). These constraints can impair the much-needed sustainable intensification of livestock production and the provision of ecosystem services in tropical pastures (Dias-Filho, 2011).

A previous study has shown that co-inoculation of Pseudomonas fluorescens and Burkolderia pyrrocinia promotes growth in Brachiaria brizantha (Lopes et al., 2018). Our hypothesis is that these rhizobacteria are a promising microbial biotechnology, able to be used as biofertilizer, to affect anatomical and biochemistry characteristics of a tropical forage grass, that stimulate improvements in nutritional value and biomass production, being an alternative chemical fertilizer. This is a relevant study to tropical pasture management and a promising solution for a more eco-friendly and sustainable pasture-based livestock production. The aim of this study was to evaluate the effects of plant growth-promoting rhizobacteria on anatomical characteristics and nutritional value of Brachiaria (Syn. Urochloa) brizantha cv. BRS Piatã.

\section{Materials and Methods}

\subsection{Experimental Design and Bacterial Strain}

The experiment was conducted at the Plant Protection Laboratory and in a semi-controlled environment in the nursery seedling production unit of the Federal Rural University of Amazonia (Universidade Federal Rural da Amazônia-UFRA) (01²7'25 "S, 48²6'36" W) in Belém, Pará, Brazil. The experimental design was completely randomized with three treatments: (1) non-inoculated unfertilized-controls B. brizantha plants (C-), (2) non-inoculated fertilized-control plants $(\mathrm{C}+)$ and (3) plants inoculated with Pseudomonas fluorescens (BRM-32111) and Burkholderia pyrrocinia (BRM-32113). Each treatment had ten replicates. The bacterial isolates were cultured in solid 523 medium (Kado et al., 1970) for $48 \mathrm{~h}$ at $28 \circ \mathrm{C}$. The bacterial suspension was prepared in water and adjusted to $\mathrm{A} 540=0.2$ (10 $\left.{ }^{8} \mathrm{CFU}\right)$ (Lopes et al., 2018).

\subsection{Plant Growth Conditions}

Brachiaria (Syn. Urochloa) brizantha cv. BRS Piatã seeds were sown in polyethylene pots $(15 \times 25 \times 0.5 \mathrm{~cm}$ ) filled with low-fertility soil of pasture in the tropics (Ferralsol - pH, 4,2; organic matter, 18,80 $\mathrm{g} \mathrm{dm}^{-3} ; \mathrm{P}, 2 \mathrm{mg} \mathrm{dm}^{-3} ; \mathrm{K}, 4 \mathrm{mg} \mathrm{dm}^{-3}$; Ca, 0,2 mmolc dm${ }^{-3}$; Ca+Mg, 0,3 mmolc dm ${ }^{-3}$; Al, 1,4 mmolc dm ${ }^{-3}$ ). Fertilized-control plants were fertilized with $5 \mathrm{mg} \mathrm{dm}^{-3}$ of $\mathrm{N}, 14 \mathrm{mg} \mathrm{dm}^{-3}$ of $\mathrm{P}_{2} \mathrm{O} 5$, and $10 \mathrm{mg} \mathrm{dm}^{-3}$ of $\mathrm{K} 2 \mathrm{O}$. Suspension of bacterial isolates $\left(5 \mathrm{~mL}, 10^{8}\right.$ $\mathrm{CFU}$ ), water drenched the trial soil at 14 days after seedling emergence (DASE) (Lopes et al.,2018). The experiment was conducted with photosynthetically active radiation of 900 $\mu \mathrm{mol} \mathrm{m} \mathrm{m}^{-2}$, mean air temperature of $30^{\circ} \mathrm{C}$ and relative humidity of $74 \%$. 


\subsection{Leaf Gas Exchange and SPAD Index}

The net $\mathrm{CO} 2$ assimilation rate (A) was determined 35 DASE, on one young, fully expanded blade per plant, with an infrared gas analyzer (IRGA) (LI-6400XT; LICOR, Lincoln, NE). Measurements were made under $\mathrm{CO}^{2}$ of $400 \mu \mathrm{mol} \mathrm{m}-1$ and a constant photosynthetic active radiation of $1000 \mu \mathrm{mol} \mathrm{m} \mathrm{m}^{-2} \mathrm{~s}^{-1}$ (obtained by an artificial light source coupled to the IRGA chamber). Water-use efficiency (WUE) was calculated as the ratio of photosynthesis to transpiration. The SPAD index (soil plant analysis development) was measured in the youngest fully expanded leaf blade. Each SPAD index value was the mean of five readings per leaf. A portable chlorophyll meter was used (SPAD-502. Konica Minolta Sensing, INC. Japan).

\subsection{Anatomical Characteristics}

At 35 DASE, leaf, culm and root samples were collected and fixed in FAA solution 50\% (ethanol: glacial acetic acid: formaldehyde). The anatomical study was performed at the Laboratory of Plant Anatomy, Department of Botany, Emilio Goeldi Museum, (Museu Paraense Emílio Goeldi) MPEG. The samples were dehydrated in a graded ethanol series and embedded in hydroxyethyl methacrylate (Leica ${ }^{\circledR}$, Germany). The blocks were cross sectioned on a rotating microtome Leica RM 2265. Section of roots and stems samples were $8 \mu \mathrm{m}$ thick, while leaves were $5 \mu \mathrm{m}$ thick. The sections were stained with $0.05 \%$ toluidine blue in acetate buffer, pH 4.3 (O'brien et al., 1964), and mounted in synthetic resin Entellan®.

The observations and measurements were carried out under BX61 Olympus microscope (Japan) with coupled digital camera connected to a computer containing the software Motic 2.0. The anatomical parameters measured were in leaf - thickness of the adaxial and abaxial epidermis and area of the bulliform cells, xylem, phloem, sclerenchyma, vascular bundles, bundle sheath, mesophyll chlorophyll and number of vascular bundles. In culm - epidermis, vascular bundles area and number of vascular bundles. In root - epidermis, exodermis, parenchyma, cortex, endoderm, pericycle, vascular cylinder, numbers of metaxylem, numbers of protoxylem and xylem diameter.

\subsection{Plant Growth, Biomass Production and Nutrients Acquisition}

the height $(\mathrm{H})$ and root length were determined at 35 DASE, and seedlings were separated into shoot (leaf blades and culms) and roots. The root area was estimated by using ImageJ (Tajima and Kato, 2011; Schneider et al., 2012). Plant material was oven dried $\left(60^{\circ} \mathrm{C}\right)$ until constant mass. Total dry mass (TDM) was calculated by adding shoot dry mass (SDM) and root dry mass (RDM). Mineral analysis of N, C, P, K, Mg and Ca, as well as, of B, Fe, Zn and $\mathrm{Cu}$ were determined by inductively coupled plasma optical emission spectrometry (ICPOES). The neutral detergent fibre (NDF) and acid detergent fibre (ADF) on a DM basis were assayed using the procedure described by Van Soest et al., (1991). N contents (DM basis) were analyzed according to the Kjeldahl. Crude protein (CP) was then calculated by multiplying the $\mathrm{N}$ content $(\%)$ by 6.25 . 


\subsection{Biochemical Assays}

Photosynthetic pigments were extracted in ethanol from leaf samples (10 mg FM) macerated in $250 \mu \mathrm{L}$ of $98 \%$ ethanol, and the pellet (precipitate) was subjected to two more extractions, using $80 \%$ ethanol and 50\% ethanol. Each extraction was incubated at $80{ }^{\circ} \mathrm{C}$ for $20 \mathrm{~min}$ and centrifuged at $12000 \mathrm{~g}$ for $5 \mathrm{~min}$ at $4{ }^{\circ} \mathrm{C}$. The resulting supernatants were collected and homogenized. The absorbance of the samples was determined at 645 and $665 \mathrm{~nm}$ (Porra et al.,1989; Lichtenthaler, 1987). For determination of the total soluble carbohydrates, $50 \mathrm{mg}$ DM incubated with $5 \mathrm{~mL}$ of sterile distilled water at $100^{\circ} \mathrm{C}$ for $30 \mathrm{~min}$ and was centrifuged at $2.000 \mathrm{~g}$ for $5 \mathrm{~min}$ at $20^{\circ} \mathrm{C}$ and the supernatant was removed. The quantification of the total soluble carbohydrates at $490 \mathrm{~nm}$ according to Dubois et al., (1956) and glucose was used as a standard.

For the determination of starch content, $50 \mathrm{mg}$ DM were incubated with $5 \mathrm{~mL}$ of ethanol at $80^{\circ} \mathrm{C}$ for $30 \mathrm{~min}$, centrifuged at $2.000 \mathrm{~g}$ for $10 \mathrm{~min}$ at $25^{\circ} \mathrm{C}$, and the supernatant was removed. In addition, a second extraction was carried out with the same milled material incubated with $5 \mathrm{~mL}$ of $30 \% \mathrm{HClO} 4$ at $25^{\circ} \mathrm{C}$ for $30 \mathrm{~min}$ and centrifuged in conditions previously described. The supernatants of the two extractions were mixed. The quantifications of the total soluble carbohydrates and starch were carried out at $490 \mathrm{~nm}$ according to Dubois et al. (1956), using glucose as a standard.

\subsection{Statistical Analyses}

All data were subjected to analysis of variance and variables with significant $F$ values were compared by Duncan test $(\mathrm{P}<0.05)$. The statistical package STATISTICA for Windows release 7 (StatSoft, Inc., Tulsa, USA) was used for all computations of the data.

\section{Results and Discussion}

Results revealed that $P$. fluorescens and B. pyrrocinia modified the anatomy and biochemistry of $B$. brizantha, promoting growth and nutrient accumulation. The higher nutrient concentration in the leaves of co-inoculated plants, especially that of nitrogen, as well as the lager bundle sheath area and mesophyll cells (Table 1; Figure 1), resulted in an increased concentration of photosynthetic pigments (chlorophyll) $(\mathrm{P}<0.001)$ (Figure 2a). The higher nitrogen content in inoculated plants was corroborated by the higher Spad index in co-inoculated plants $(\mathrm{P}<0.01$ ) (Table 2; Figure $2 \mathrm{~b}$ ), which should present values higher than 40 (Reis et al., 2013). When fertilized with nitrogen, tree species showed a larger xylem diameter, which increased water and nutrients transport, contributing to plant development (Wang et al., 2018).

The higher nutrient uptake in co-inoculated plants might also have resulted from anatomical changes induced by the rhizobateria in roots. In root, the rhizobacteria increased by more than $50 \%$ the exoderme, pericycle, parenchyma and vascular cylinder, by $30 \%$ the protoxilema and the diameter of the xylem cells and by $10 \%$ the endoderm relative to control plants $(\mathrm{P}<$ 0.01) (Table 1; Figure 1 (g-i)). Higher $\mathrm{K}$ and Mg concentrations $(\mathrm{P}<0.01)$ (Table 2) were resulted increased exodermis, pericycle (Tabela 1; Figure 1); also, the probably the consequence of the increase in auxin, promoting oxygen diffusion from the base to the apex, 


\section{Macrothink}

increasing xylem, protoxilem and root area (Figure 1 and Figure 2).
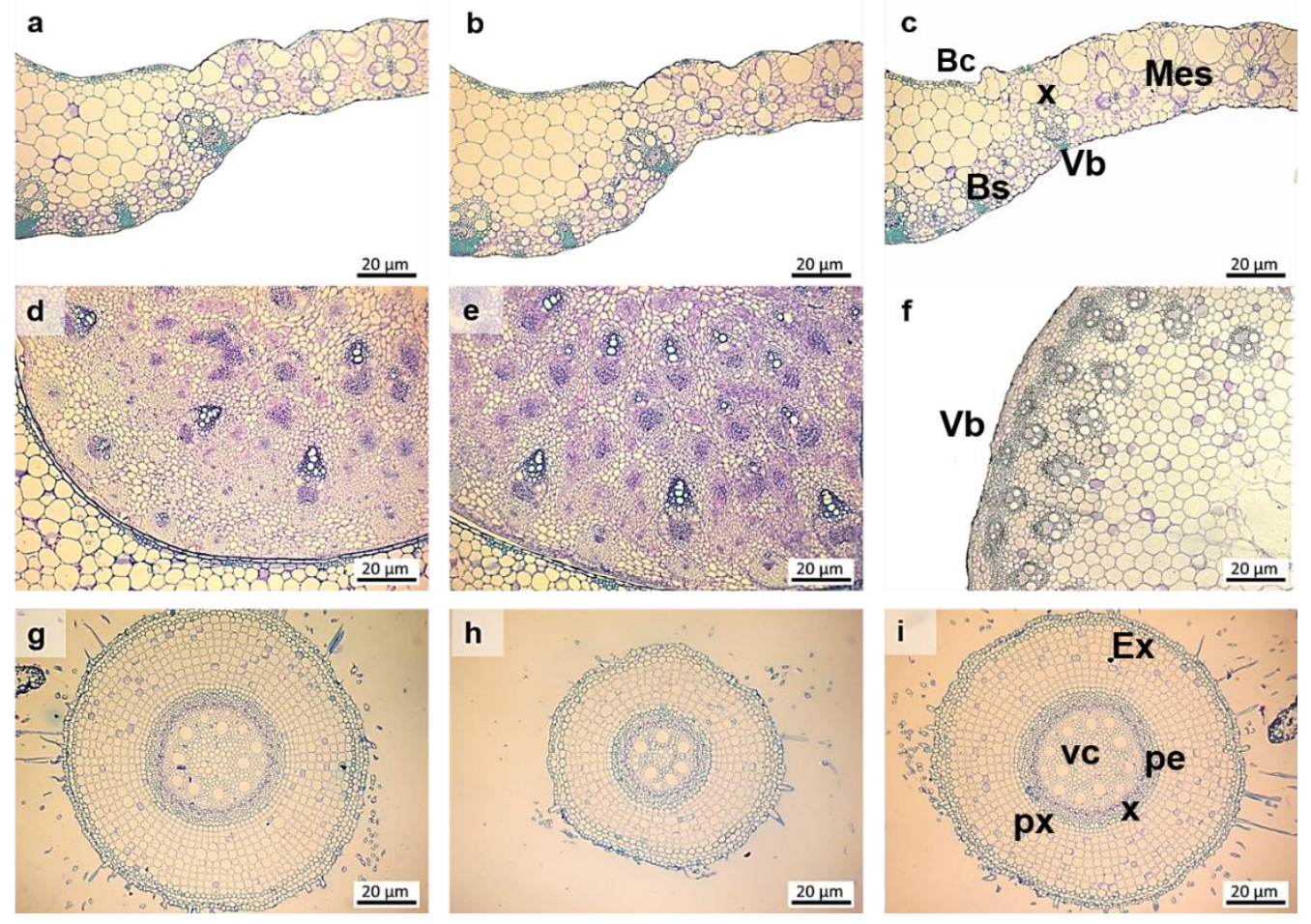

Figure 1. Brachiaria brizantha cross sections leaf (a-c), culm (d-f) and root (g-i). Unfertilized $(\mathrm{a}, \mathrm{d}, \mathrm{g})$ or fertilized non-inoculated control plants (b, e, h) and co-inoculated with Pseudomonas fluorescens and Burkholderia pyrrocinia (c, f, i). Buliform cells (Bc), bundle sheath (Bs), Vascular bundles (Vb), xylem (x), mesophyll (Mes), exodermis (Ex), pericycle (pe), vascular cylinder (vc) and protoxylem (px) 
Table 1. Anatomical parameters $\left(\mu \mathrm{m}\right.$ or $\mu \mathrm{m}^{2}$ ) of Brachiaria brizantha under the three treatments: unfertilized $(\mathrm{C}-)$, fertilized $(\mathrm{C}+)$ non-inoculated control plants and co-inoculated with Pseudomonas fluorescens and Burkholderia pyrrocinia (MIX)

\begin{tabular}{|c|c|c|c|c|}
\hline \multicolumn{2}{|c|}{ Parameters } & $\mathrm{C}-$ & $\mathrm{C}+$ & Mix \\
\hline \multirow{10}{*}{ Leaf } & Adaxial epidermis $(\mu \mathrm{m})$ & $11.54(0.11) b$ & $11.86(0.15) b$ & $20.24(0.11) \mathrm{a}$ \\
\hline & Abaxial epidermis $(\mu \mathrm{m})$ & $16.60(0.33) \mathrm{c}$ & $25.49(0.29) \mathrm{a}$ & $23.33(0.08) b$ \\
\hline & Bulliform cells area $\left(\mu \mathrm{m}^{2}\right)$ & $12828.99(32.1) b$ & $12703.61 \quad(36.07)$ & $16594,07(47.45) \mathrm{a}$ \\
\hline & & & & \\
\hline & Xylem area $\left(\mu \mathrm{m}^{2}\right)$ & $8100.35(27.67) \mathrm{c}$ & $8869.52(73.88) b$ & $9116.19(15.64) \mathrm{a}$ \\
\hline & Phloem area $\left(\mu \mathrm{m}^{2}\right)$ & $3147.13(22.63) \mathrm{a}$ & $2160.41(16.88) \mathrm{c}$ & $2830,56 \mathrm{~b}$ \\
\hline & Sclerenchyma area $\left(\mu \mathrm{m}^{2}\right)$ & $1171.01(4.84) b$ & $1472.41(7.48) \mathrm{a}$ & $800.97(16.70) \mathrm{c}$ \\
\hline & Vascular bundles area $\left(\mu \mathrm{m}^{2}\right)$ & $3058.87(7.08) b$ & $2686.55(24.27) \mathrm{c}$ & $3200.26(10.19) \mathrm{a}$ \\
\hline & Bundle sheath area $\left(\mu \mathrm{m}^{2}\right)$ & $18862.34(115.13) \mathrm{c}$ & $\begin{array}{l}21484.33(40.81) \\
\text { b }\end{array}$ & $\begin{array}{ll}24316.82 & (108.05) \\
\mathrm{a} & \end{array}$ \\
\hline & $\begin{array}{l}\text { Mesophyll chlorophyll area } \\
\left(\mu \mathrm{m}^{2}\right)\end{array}$ & $193524.01(95.44) b$ & $\begin{array}{l}188700.81(77.19) \\
\mathrm{c}\end{array}$ & $\begin{array}{l}211559.31(146.61) \\
\mathrm{a}\end{array}$ \\
\hline \multirow[t]{3}{*}{ Culm } & Epidermis $(\mu \mathrm{m})$ & $13.47(0.11) \mathrm{c}$ & $18.46(0.12) \mathrm{a}$ & $14.07(0.02) \mathrm{b}$ \\
\hline & Vascular bundles area $\left(\mu \mathrm{m}^{2}\right)$ & $1989.95(581.06) \mathrm{c}$ & $\begin{array}{l}10089.77(183.57) \\
\text { b }\end{array}$ & $20364.01(96.54)$ a \\
\hline & Number of vascular bundles & $33.57(0.24) \mathrm{c}$ & $42.48(0.27) \mathrm{b}$ & $69.12(0.13) \mathrm{a}$ \\
\hline \multirow{11}{*}{ Root } & Epidermis $(\mu \mathrm{m})$ & $14508.01(453.32) \mathrm{a}$ & $13037.02(182.07)$ & $\begin{array}{ll}12734.13 & (323.62) \\
c\end{array}$ \\
\hline & Exodermis $(\mu \mathrm{m})$ & $18873.81(236.22) b$ & $14179.94(235.39)$ & $23063.50 \quad(719.17)$ \\
\hline & & & c & a \\
\hline & Parenchyma $(\mu \mathrm{m})$ & $7985(262.74) b$ & 0 & $\begin{array}{l}12302,56(403.39) \\
a\end{array}$ \\
\hline & Cortex $(\mu \mathrm{m})$ & $209883.81(1581.32) \mathrm{a}$ & $\begin{array}{l}145267.23 \\
(307.23) \mathrm{c}\end{array}$ & $\begin{array}{l}153069.71 \\
(1648.16) \mathrm{b}\end{array}$ \\
\hline & Endoderm $(\mu \mathrm{m})$ & $12954.78(308.57) \mathrm{c}$ & $\begin{array}{l}14006.01(391.96) \\
b\end{array}$ & $\begin{array}{ll}14693.67(542.91) \\
\mathrm{a}\end{array}$ \\
\hline & Pericycle $(\mu \mathrm{m})$ & $25278.37(304.21) b$ & $\begin{array}{l}23272.28(440.33) \\
\mathrm{c}\end{array}$ & $\begin{array}{ll}37372.27 & (321.22) \\
\mathrm{a} & \end{array}$ \\
\hline & Vascular cylinder $(\mu \mathrm{m})$ & $338050.4(2572.79) \mathrm{a}$ & $\begin{array}{l}190090.8 \\
(1983.32) \mathrm{b}\end{array}$ & $\begin{array}{c}337155.31(321.22) \\
\mathrm{a}\end{array}$ \\
\hline & Numbers of metaxylem & $16.52(0.12) \mathrm{a}$ & $8.24(0.17) \mathrm{c}$ & $15.30(0.21) b$ \\
\hline & Numbers of protoxylem & $31.51(0.21) b$ & $23.95(0.20) \mathrm{c}$ & $36.11(0.19) \mathrm{a}$ \\
\hline & Xylem diameter $(\mu \mathrm{m})$ & $30041.11(456.37) \mathrm{c}$ & $\begin{array}{l}38490.77(361.36) \\
b\end{array}$ & $\begin{array}{c}45667.51(501.44) \\
\mathrm{a}\end{array}$ \\
\hline
\end{tabular}

Significant at the 0.05 probability level. Data are means \pm SE. Means followed by different letters in each column are significantly different $(\mathrm{P}<0.05$, Duncan Test). 

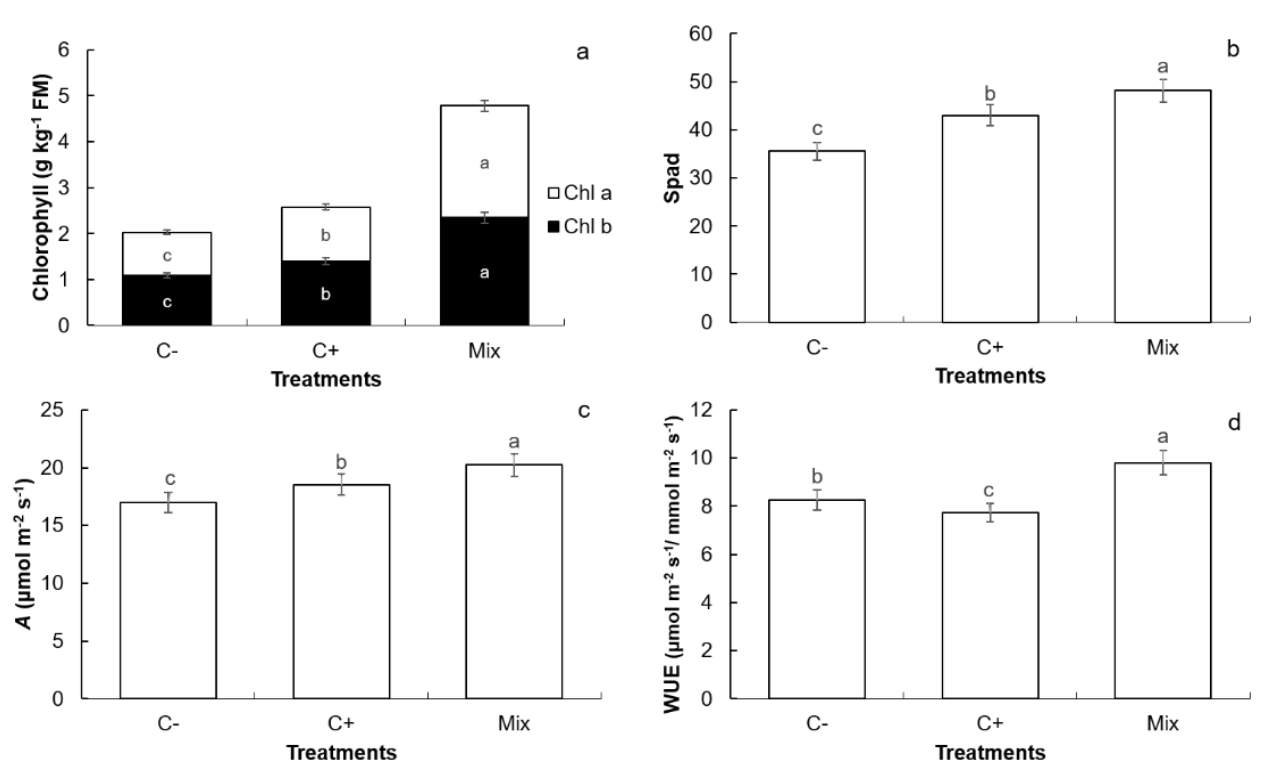

Figure 2. Leaf chlorophyll (a), Spad index (b), net photosynthesis (A) (c) and water-use efficiency (WUE) of Brachiaria brizantha with growth-promoting rhizobacteria. Means followed by different letters in each column are significantly different $(\mathrm{P}<0.05$, Duncan test).

$\mathrm{C}$ - = unfertilized-control; $\mathrm{C}+=$ fertilized-control; Mix $=$ Burkholderia pyrrocinia + Pseudomonas fluorescens

The greater vascular system development in leaf, culm and root (Table 1; Figure 1), might have contributed to increase water and nutrient transport, resulting in a greater photosynthetic efficiency (Figure 2c) and higher total carbohydrates and starch concentration in co-inoculated plants (Figure 3). Also, growth promoting rhizobacteria increased chlorophyll concentration, photosynthetic rate and water use efficiency in Phaseolus coccineus (Stefan et al., 2013); total carbohydrates and protein content in and Arachis hypogaea (Mathivanan et al., 2017).
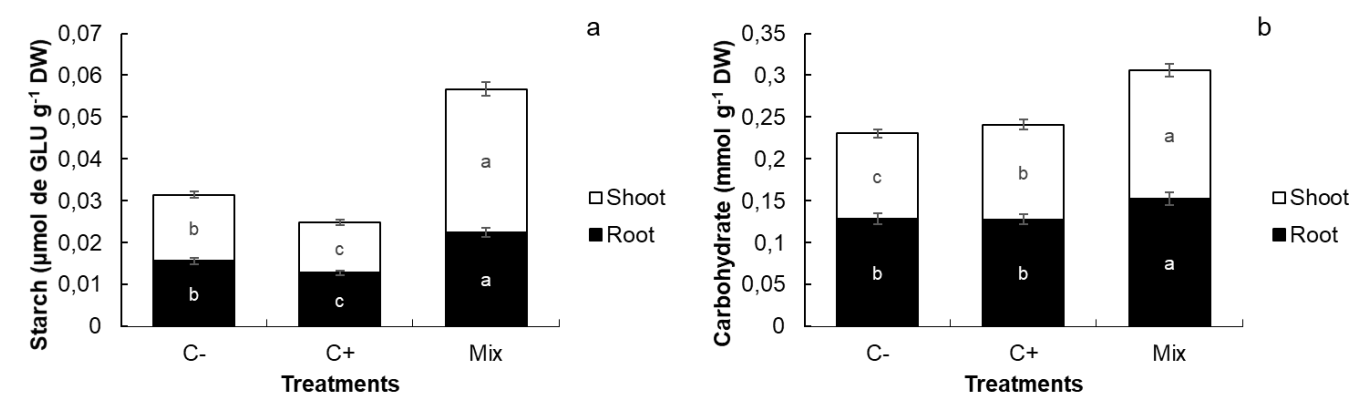

Figure 3. Starch (a) and total carbohydrate (b) of Brachiaria brizantha with growth-promoting rhizobacteria. Means followed by different letters in each column are significantly different $(\mathrm{P}<0.05$, Duncan Test). $\mathrm{C}-=$ unfertilized-control; $\mathrm{C}+=$ fertilized-control; Mix = Burkholderia pyrrocinia + Pseudomonas fluorescens 
It is possible to infer that co-inoculation would increase tolerance to grazing and water deficit of $B$. brizantha. This is because co-inoculated plants had a greater development of the root and vascular systems, higher photosynthetic rate, starch concentration, water-use efficiency, and bulliform cells area, which are responsible for leaf curling for reducing transpiration (Reis et al., 2013). In culm, the rhizobacteria induced the increased vascular bundles. Only inoculated plants showed sclerenchyma ring, with 2-5 layers of cells and hollow medulla $(\mathrm{P}<$ 0.001) (Figure 1f). This characteristic could make these plants more resistant to lodging (Reis et al., 2013). Rhizobacteria inoculation also increased vascular development in Triticum aestivum (El-Afry et al., 2012), and root density in Handroanthus impetiginosus (Larraburu and Llorente, 2015).

Co-inoculation increased the concentrations of macro and micronutrients in leaves $(\mathrm{N}, \mathrm{P}, \mathrm{Na}$, $\mathrm{Mg}, \mathrm{Fe}$ and $\mathrm{Cu}$ ) and roots $(\mathrm{N}, \mathrm{P}, \mathrm{K}, \mathrm{Na}, \mathrm{Mg}, \mathrm{Fe}, \mathrm{Cu}$ and $\mathrm{Mn}$ ), improving the nutritional quality of $B$. brizantha $(\mathrm{P}<0.05)$ (Table 2). Crude protein content $(\mathrm{CP})$ was higher in co-inoculated plants, with an increase of $37 \%$ and $18 \%$ relative to unfertilized-control plants and fertilized-control plants, respectively (Table 2). A direct consequence of the higher nitrogen content in leaves of $B$. brizantha was the increase in crude protein (CP) content, an important forage quality property for ruminant nutrition (Reis et al., 2013; Ball et al., 2015). The increase in CP content and biomass production, observed in co-inoculated plants (Table 2, Figure 4), is a common response to nitrogen fertilization in B. brizantha (Pontes et al., 2017) and in Panicum maximum (Paciullo et al., 2017). 
Table 2. Macro and micronutrients concentrations, neutral detergent fiber (NDF), acid detergent fiber (ADF) and crude protein (CP) of Brachiaria brizantha under the three treatments: unfertilized $(\mathrm{C}-)$, fertilized $(\mathrm{C}+)$ non-inoculated control plants and co-inoculated with Pseudomonas fluorescens and Burkholderia pyrrocinia (MIX)

\begin{tabular}{|c|c|c|c|c|c|c|}
\hline \multirow{2}{*}{ Parameters } & \multicolumn{3}{|c|}{ Shoot } & \multicolumn{3}{|c|}{ Root } \\
\hline & $\mathrm{C}-$ & $\mathrm{C}+$ & Mix & C- & $\mathrm{C}+$ & Mix \\
\hline $\mathrm{N}(\mathrm{g} / \mathrm{kg})$ & $\begin{array}{c}23.19 \\
(0.78) \mathrm{c}\end{array}$ & $\begin{array}{c}27.08(0.74) \\
b\end{array}$ & $\begin{array}{c}30.08(0.61) \\
a\end{array}$ & $4.14(0.12) \mathrm{c}$ & $5.96(0.15) b$ & $7.49(0.24) \mathrm{a}$ \\
\hline $\mathrm{P}(\mathrm{g} / \mathrm{kg})$ & $\begin{array}{c}1.07(0.02) \\
\mathrm{c}\end{array}$ & $\begin{array}{c}1.17(0.05) \\
b\end{array}$ & $1.22(0.03) \mathrm{a}$ & $\begin{array}{c}0.07(0.002) \\
\mathrm{b}\end{array}$ & $\begin{array}{c}0.08(0.002) \\
b\end{array}$ & $\begin{array}{c}0.17(0.001) \\
\mathrm{a}\end{array}$ \\
\hline $\mathrm{K}(\mathrm{g} / \mathrm{kg})$ & $\begin{array}{l}24.39 \\
(0.58)\end{array}$ & $23.66(0.31)$ & $22.71(1.23)$ & $8.12(0.32) \mathrm{c}$ & $9.83(0.01) b$ & $\begin{array}{c}14.74(0.01) \\
\mathrm{a}\end{array}$ \\
\hline $\mathrm{Na}(\mathrm{g} / \mathrm{kg})$ & $0.6(0.01) \mathrm{c}$ & $\begin{array}{c}0.77(0.04) \\
b\end{array}$ & $0.81(0.03) \mathrm{a}$ & $1.16(0.15) \mathrm{c}$ & $1.52(0.06) b$ & $1.96(0.02) \mathrm{a}$ \\
\hline $\mathrm{Ca}(\mathrm{g} / \mathrm{kg})$ & $\begin{array}{c}5.94(0.14) \\
\mathrm{c}\end{array}$ & $\begin{array}{c}6.88(0.07) \\
\mathrm{a}\end{array}$ & $6.79(0.11) b$ & $1.12(0.01) b$ & $1.53(0.05) \mathrm{a}$ & $1.09(0.03) b$ \\
\hline $\mathrm{Mg}(\mathrm{g} / \mathrm{kg})$ & $\begin{array}{c}4.56(0.12) \\
\mathrm{c}\end{array}$ & $\begin{array}{c}5.76(0.07) \\
b\end{array}$ & $5.86(0.09) \mathrm{a}$ & $\begin{array}{c}0.66(0.003) \\
\mathrm{c}\end{array}$ & $\begin{array}{c}0.75(0.002) \\
\mathrm{b}\end{array}$ & $1.08(0.02) \mathrm{a}$ \\
\hline $\mathrm{Fe}(\mathrm{g} / \mathrm{kg})$ & $\begin{array}{c}191.02 \\
(1.98) \mathrm{c}\end{array}$ & $\begin{array}{c}212.50 \\
(5.24) \mathrm{b}\end{array}$ & $\begin{array}{c}542.69 \\
(46,67) \mathrm{a}\end{array}$ & $\begin{array}{c}2176.9 \\
(23.27) \mathrm{c}\end{array}$ & $\begin{array}{l}2350.5 \\
(60.34) b\end{array}$ & $\begin{array}{l}3143.6 \\
(26.75) \mathrm{a}\end{array}$ \\
\hline $\mathrm{Zn}(\mathrm{g} / \mathrm{kg})$ & $\begin{array}{c}97.12(5.4) \\
\mathrm{c}\end{array}$ & $\begin{array}{l}149.13 \\
(7.37) \mathrm{a}\end{array}$ & $\begin{array}{c}123.37 \\
(3.97) b\end{array}$ & $\begin{array}{c}80.86(4.12) \\
\mathrm{a}\end{array}$ & $\begin{array}{c}78.98(8.37) \\
\text { b }\end{array}$ & $\begin{array}{c}67.03(5.28) \\
\mathrm{c}\end{array}$ \\
\hline $\mathrm{Cu}(\mathrm{g} / \mathrm{kg})$ & $\begin{array}{l}13.29 \\
(0.24) \mathrm{c}\end{array}$ & $\begin{array}{c}14.14(0.15) \\
\mathrm{b}\end{array}$ & $\begin{array}{c}14.61(0.14) \\
\mathrm{a}\end{array}$ & $3.91(0.16) \mathrm{c}$ & $5.62(0.12) \mathrm{a}$ & $4.96(0.04) b$ \\
\hline Mn (g/kg) & $143.02 \mathrm{c}$ & $169.24 \mathrm{a}$ & $145.06 \mathrm{~b}$ & $\begin{array}{c}53.26(1.54) \\
c\end{array}$ & $\begin{array}{c}61.05(5.65) \\
\mathrm{b}\end{array}$ & $\begin{array}{c}74.57(3.47) \\
\mathrm{a}\end{array}$ \\
\hline $\begin{array}{c}\mathrm{NDF}\left(\mathrm{g} \mathrm{kg}^{-1} \text { of }\right. \\
\mathrm{DM})\end{array}$ & $260(22.5)$ & $251(12.32)$ & $260(23.4)$ & & & \\
\hline $\begin{array}{l}\mathrm{ADF}\left(\mathrm{g} \mathrm{kg}^{-1} \text { of }\right. \\
\mathrm{DM}) \\
\mathrm{CP}\left(\mathrm{g} \mathrm{kg}^{-1} \text { of }\right. \\
\mathrm{DM})\end{array}$ & $\begin{array}{c}130(45.6) \\
\mathrm{b} \\
157.6 \\
(11.2) \mathrm{c}\end{array}$ & $\begin{array}{c}150(21.3) \mathrm{a} \\
183.3(9.6) \\
\mathrm{b}\end{array}$ & $\begin{array}{c}132(23.76) \\
\mathrm{b} \\
215.8(42.3) \\
\mathrm{a}\end{array}$ & & & \\
\hline
\end{tabular}

Significant at the 0.05 probability level. Data are means \pm SE. Means followed by different letters in each column are significantly different $(\mathrm{P}<0.05$, Duncan Test).

Phosphorus $(\mathrm{P})$ is a limiting nutrient essential for pasture establishment and productivity (Dias-Filho, 2011). In some situations, part of the available phosphorus, in phosphorus-containing fertilizers may be readily bound to the soil, resulted in low $\mathrm{P}$ availability to plants (Dias-Filho, 2011; Pii et al., 2015; Duchene, et al., 2017). Oliveira Neto et al. (2020) verified that nitrogen and phosphorus supply in soil, increase dry mass production in Panicum maximum cv. BRS Zuri. The higher P content observed in inoculated plants suggests that the rhizobacteria increased soil $\mathrm{P}$ availability and $\mathrm{P}$ uptake by $B$. brizantha (Table 2). It is possible to infer that inoculation, besides contributing to increase pasture productivity, would also contribute to improve animal nutrition, reducing the need for P supplementation in animal diet, a common practice in tropical pastures systems (Dias-Filho, 2011). 


\section{Macrothink}
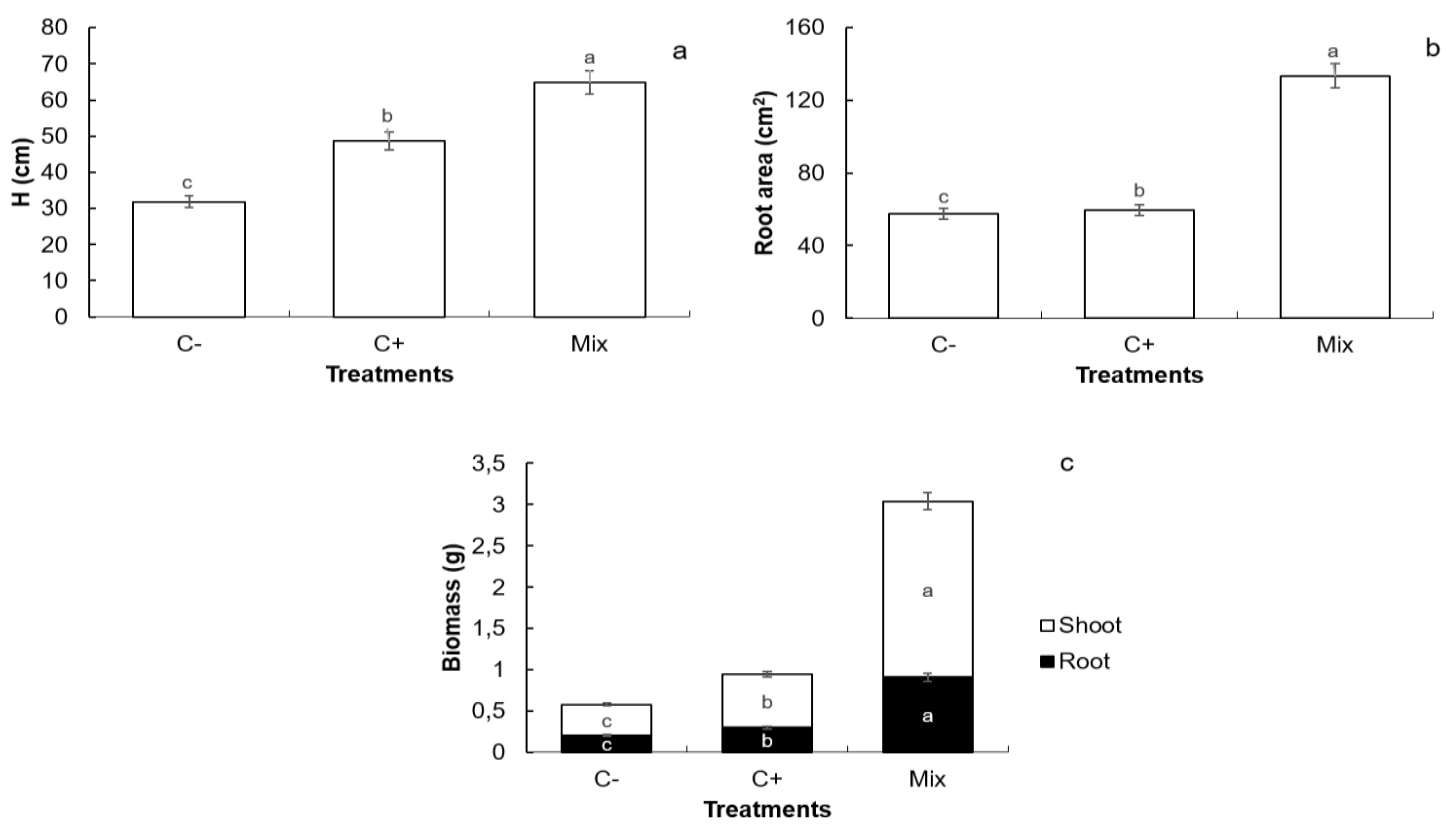

Figure 4. Plant height (H) (a) and root area (b) and biomass production (c) of Brachiaria brizantha with growth-promoting rhizobacteria. Means followed by different letters in each column are significantly different $(\mathrm{P}<0.05$, Duncan Test $) . \mathrm{C}-=$ unfertilized-control; $\mathrm{C}+=$ fertilized-control; Mix $=$ Burkholderia pyrrocinia + Pseudomonas fluorescens

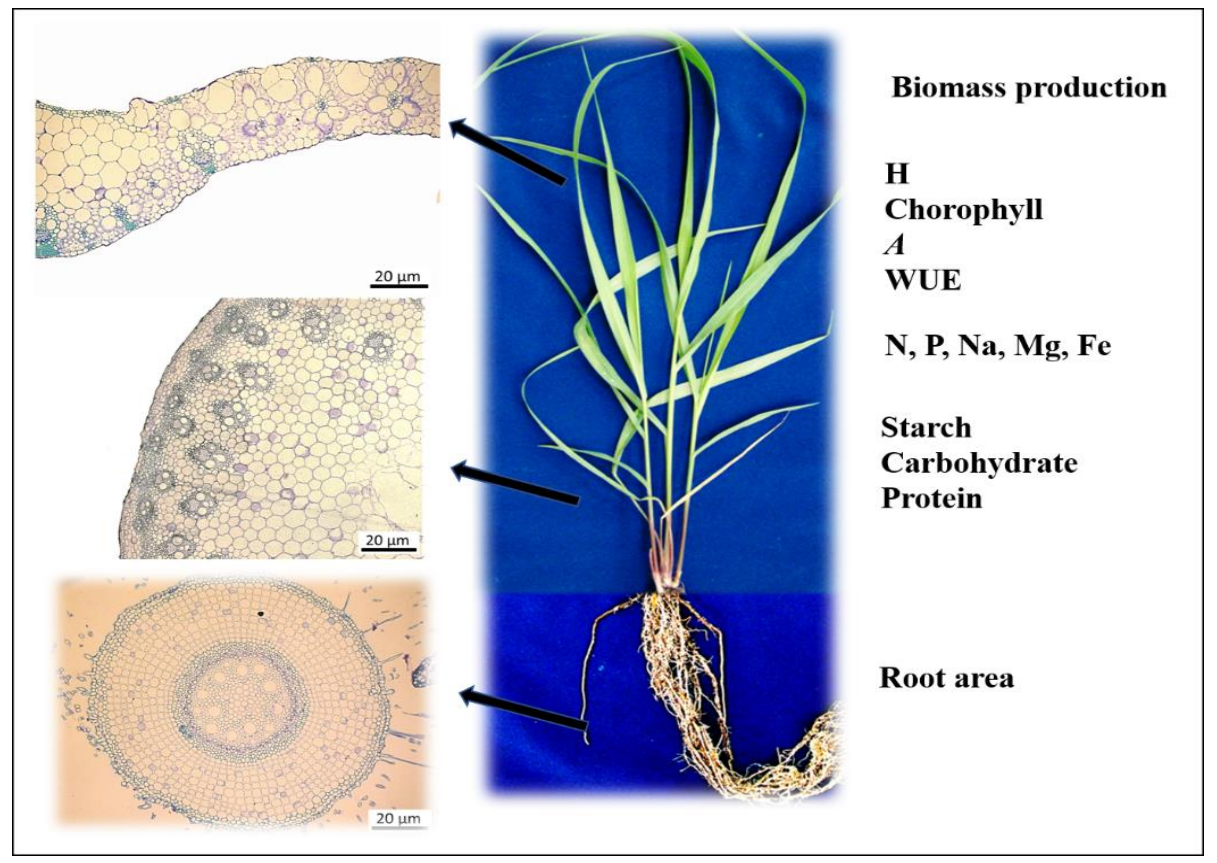

Figure 5. Brachiaria brizantha inoculated with plant growth-promoting rhizobacteria, 35 days after seedling emergence. Pseudomonas fluorescens (BRM-32111) and Burkhoderia pyrrocinia (BRM-32113) modified the anatomy (leaf, culm and root), increased the plant height $(\mathrm{H})$, chlorophyll content, net photosynthesis $(A)$, water-use efficiency (WUE), $\mathrm{N}, \mathrm{P}, \mathrm{Na}$,

$\mathrm{Mg}, \mathrm{Fe}$, starch, carbohydrate and protein contents, root area, forage quality and biomass production in $B$. brizantha 
The amount of fiber, such as neutral detergent fiber (NDF) and acid detergent fiber (ADF), which are structural carbohydrates of plant cell wall, and include cellulose, hemicellulose, lignin and pectin, are important components of forage nutritional quality (Ball et al., 2015). The NDF did not differ among treatments while ADF was higher in fertilized-control plants (Table 2). Forages with a fiber (NDF and ADF) content of over $60 \%$ have low digestibility, resulting in lower consumption and animal performance (Ball et al., 2015). It is possible to infer that $B$. brizantha co-inoculated with $P$. fluorescens and B. pyrrocinia would have a higher digestibility consumption, due to the lower thickness of the epidermis, mainly the abaxial, and the sclerenchyma area (Figura 1) (Tsuzukibashi et al., 2016; Paciullo et al., 2017).

Results of the research study pointed out that co-inoculation with $P$. fluorescens and $B$. pyrrocinia was more efficient than conventional chemical fertilization in promoting nutritional quality and biomass production in B. brizantha. (Figure 4) In the present study, rhizobacteria acted as biofertilizer in $B$. brizantha, stimulating nutrient acquisition, modifying physiology, contributing to accumulation of metabolites, resulting in increased height, forage biomass and nutritional value (Figure 5). These attributes are of great practical importance, by affecting total daily feed intake (Reis et al., 2013).

\section{Conclusion}

Co-inoculation with $P$. fluorescens (BRM-32111) and B. pyrrocinia (BRM-32113) modified the anatomy and biochemistry of $B$. brizantha, promoting growth and nutrient accumulation. Therefore, these findings set up the basis for additional exploratory studies, using these rhizobacteria as biotechnological innovation with potential of use as biofertilizer in $B$. brizantha, aiming higher productivity and nutritive value in a more eco-friendly and sustainable pasture production system.

\section{Acknowledgement}

We thank Federal Rural University of Amazonia (UFRA), Fundação Amazônia de Amparo a Estudos e Pesquisa do Pará (FAPESPA) and Museu Paraense Emílio Goeldi (MPEG) for support this research materially, financially and laboratory. We also thank Francisco Janyelo Palacios Martinez (in memorian), from Grupo Gasparim, for kindly supplying the Brachiaria brizantha cv. BRS Piatã seeds, and Walter Velasco and Lenison Ferreira for technical laboratory support and Bruno Carneiro e Pedreira from Embrapa Agrossilvipastoril for performing the nutritive and mineral analyzes. We also thank MCTIC/CNPq (444338/2018-7; Number: 300656/2019-0).

\section{References}

Ball, D. M., Hoveland, C. S., \& Lacefield, G. D. (2015). Southern Forages. 5th ed. International Plant Nutrition Institute, Peachtree Corners, GA.

Bhat, M. A., Rasool, R., \& Ramzan, S. (2019). Plant Growth Promoting Rhizobacteria (PGPR) for Sustainable and Eco-Friendly Agriculture. Acta Scientific Agriculture, 3(1), 23-25 https://actascientific.com/ASAG/pdf/ASAG-03-0287.pdf 


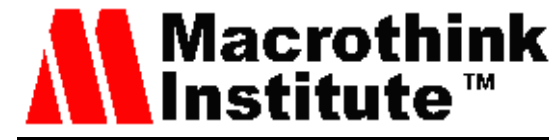

Journal of Agricultural Studies

ISSN 2166-0379

2020, Vol. 8, No. 1

Dias-Filho, M. B. (2011) Degradação de pastagens: processos, causas e estratégias de recuperação. 4ed., Belém. PA.

Dias-Filho, M. B. (2011) Degradação de pastagens: processos, causas e estratégias de recuperação. 4ed., Belém. PA.

Dias-Filho, M. B., \& Lopes, M. J. S. (2019b): Manejo do solo em pastagens. In: Bertol I, De Maria IC, Souza LS, (Eds.). Manejo e conservação do solo e da água. Viçosa, MG: Sociedade Brasileira de Ciência do Solo, 1163-1181.

Dias-Filho, M. B., \& Lopes, M. J. S. (2019a) Processos e causas de degradação de pastagens na Amazônia. In: Dias-Filho MB, Andrade CMS de (Eds.). Recuperação de pastagens degradadas na Amazônia. Brasília, DF: Embrapa, 55-78.

Dubois, M., et al. (1956) Colorimetric method for determination of sugars and related substances. Analitical Chemistry, 28, 350-356. https://doi.org/10.1021/ac60111a017

Duchene, O. et al. (2017) Intercropping with legume for agroecological cropping systems: Complementarity and facilitation processes and the importance of soil microorganisms. A review. Agriculture, Ecosystems and Environment, 240, 148-161. https://doi.org/10.1016/j.agee.2017.02.019

El-Afry, M. M. et al. (2012) Anatomical studies on drought-stressed wheat plants (Triticum aestivum L.) treated with some bacterial strains. Acta Biologica Szegediensis, 56(2), 165-174. www2.sci.u-szeged.hu/ABS/2012/Acta\%20HPb/56165.pdf

Kado, C. I., \& Heskett, M. G. (1970) Selective media for isolation of Agrobacterium, Corynebacterium, Erwinia, Pseudomonas, and Xanthomonas. Phytopathology, 60, 969-976. https://doi.org/10.1094/Phyto-60-969

Lichtenthaler, H. K. (1987). Chlorophyll sand carotenoids: pigments of photosynthetic $\begin{array}{llll}\text { biomembranes. } \quad \text { Methods } & \text { Enzymology, } & \text { 350-382. }\end{array}$ https://doi.org/10.1016/0076-6879(87)48036-1

Lopes, M. J. S., Dias-Filho, M. B., Castro, T. H. R., Filippi, M. C. C., \& Silva, G. B. (2018) Effect of Pseudomonas fluorescens and Burkholderia pyrrocinia on the growth improvement and physiological responses in Brachiaria brizantha. American Journal of Plant Sciences, 9, 250-265. https://doi.org/10.4236/ajps.2018.92021

Mathivanan, S., et al. (2017) Impact of PGPR inoculation on photosynthetic pigment and protein contents in Arachis hypogaea L. Journal of Scientific Agriculture, 1, 29-36. https://doi.org/10.25081/jsa.2017.v1i0.24

O’Brien, T. P., Feder, N., \& Mccully, M. E. (1964) Polychromatic staining of plant cell walls by toluidine blue. Protoplasma, 59, 368-373. https://doi.org/10.1007/BF01248568

Oliveira Neto, S. S. et al., (2020). Nitrogen and Phosphate Ferti lization Maximize Grass BRS Zuri Performance. Journal of Agricultural Studies, 8(1), 64-78. https://doi.org/10.5296/jas.v8i1.15521 
Paciullo, D. S. C., et al. (2017) Morphogenesis, biomass and nutritive value of Panicum maximum under different shade levels and fertilizer nitrogen rates. Grass and Forage Science, 72(3), 590-600. https://doi.org/10.1111/gfs.12264

Pagano, M. C., et al. (2017). Advances in Eco-Efficient Agriculture: The Plant-Soil Mycobiome. Agriculture, 7, 1-14. https://doi.org/10.3390/agriculture7020014

Pii Y, et al. (2015). Microbial interactions in the rhizosphere: beneficial influences of plant growth-promoting rhizobacteria on nutrient acquisition process. A review. Biol Fertil Soils, 51(4), 403-415. https://doi.org/10.1007/s00374-015-0996-1

Pontes, L. S., et al. (2017). Effects of nitrogen fertilization and cutting intensity on the agronomic performance of warm-season grasses. Grass and Forage Science, 72(4), 663-675 https://doi.org/10.1111/gfs.12267

Porra, R. J., et al. (1989). Determination of accurate extinction coefficients and simultaneous equations for assaying chlorophylls $\mathrm{a}$ and $\mathrm{b}$ extracted with four different solvents: Verification of the concentration of chlorophyll standards by atomic absorption spectroscopy. Biochem Biophys Acta, 975, 384-394. https://doi.org/10.1016/S0005-2728(89)80347-0

Reis, A. R., et al. (2013). Forragicultura: ciência, tecnologia e gestão de recursos forrageiros. $714 \mathrm{p}$.

Reis, J. C., et al. (2019). Aspectos econômicos da recuperação de pastagens na Amazônia In: Dias-Filho MB, Andrade CMS de (Eds.). Recuperação de pastagens degradadas na Amazônia. Brasília, DF: Embrapa, 385-413.

Richardson, A. E, et al. (2009). Acquisition of phosphorus and nitrogen in the rhizosphere and plant growth promotion by microorganisms. Plant and Soil, 321, 305-339. https://doi.org/10.1007/s11104-009-9895-2

Schneider, C. A., et al. (2012). NIH Image to Image J: 25 years of image analysis. Nature Methods, 9, 671-675. https://doi.org/10.1038/nmeth.2089

Stefan, M. et al. (2013) Seed inoculation with plant growth promoting rhizobacteria enhances photosynthesis and yield of runner bean (Phaseolus coccineus L.). Scientia Horticulturae, 151, 22-29. https://doi.org/10.1016/j.scienta.2012.12.006

Tajima, R., \& Kato, Y. (2011). Comparison of threshold algorithms for automatic image processing of rice roots using freeware ImageJ. Field Crops Research, 121, 460-463. https://doi.org/10.1016/j.fcr.2011.01.015

Tsuzukibashi, D. et al. (2016). Quantitative anatomy, in vitro digestibility and chemical composition of Brachiaria brizantha cultivars. Revista de Ciências Agrárias, 39(1), 46-53. https://doi.org/10.19084/RCA14141

Van Soest, P. J. et al. (1991). Methods for dietary fiber, neutral detergent fiber, and nonstarch polysaccharides in relation to animal. Journal of Dairy Science, 74(10), 3583-3597 https://doi.org/10.3168/jds.S0022-0302(91)78551-2 
Wang, W., et al. (2018). Linkage of root morphology to anatomy with increasing nitrogen availability in six temperate tree species. Plant and Soil, 425, 189-200. https://doi.org/10.1007/s11104-018-3563-3

\section{Copyright Disclaimer}

Copyright for this article is retained by the author(s), with first publication rights granted to the journal.

This is an open-access article distributed under the terms and conditions of the Creative Commons Attribution license (http://creativecommons.org/licenses/by/4.0/). 